www.globaljournalseries.com, Email: info@globaljournalseries.com

\title{
STATUS EVALUATION OF HEAVY METALS IN WASTE DISPOSAL SITES OF CHAMPION BREWERIES AND PLASTO CROWN COMPANY, UYO, AKWA IBOM STATE, NIGERIA
}

U. S. UMANA

\begin{abstract}
Sludge and soil samples were collected through purposive sampling method within Champion Breweries and Plasto Crown Company waste disposal sites during wet and dry seasons for status evaluation of their heavy metals $(\mathrm{Fe}, \mathrm{Pb}, \mathrm{Zn}, \mathrm{Ni}, \mathrm{Cr}, \mathrm{Cd}$, Co and $\mathrm{Hg}$ ) for comparison with the control site and the world threshold standards for tropical soils. The results showed that the sludge $\mathrm{pH}$ value of 7.89 during wet season signified alkaline medium (outside the natural range of acidic medium for soils in the Niger Delta region of Nigeria) which was attributed to the high calcium content of the brewery effluent. The $7.42 \mathrm{pH}$ value during wet season for soil in the Plasto Crown Company waste disposal site indicated alkaline medium which was due to the remnants of the wastes which formed lime to neutralize the acidic medium of the soil while the electrical conductivity values (below $4 \mathrm{dSm}^{-1}$ ) indicated the nonsalinity of the soils. More so, a two way analysis of variance (ANOVA) statistical method used to run the analysis revealed that the soil in terms of heavy metal concentrations did not exceed the world threshold standards.
\end{abstract}

KEYWORDS: Soil, sludge, heavy metal concentrations, permissible standards.

\section{INTRODUCTION}

Environmental contamination by heavy metals such as cadmium, lead, zinc and copper has been of great concern in the last decade to the entire world because they constitute health hazards to man and other organisms when accumulated within the biological systems. According to Sule (2001), plants grown on contaminated soils transfer trace elements into human bodies on consumption of such plants. Heavy metals have relatively high atomic weight. Therefore, problems arise when they are converted by hydrological or biological processes until they become hazardous to natural ecosystems and human health (Martin et al., 1982).

Heavy metals such as lead, mercury, copper, arsenic, chromium, zinc and cadmium discharged into the ecosystems are then picked up by benthic organisms and enter the food chain. Notably, most of these hazardous wastes are discharged by industries (Asthana and Asthana, 2001). For instance, industrial wastes discharged in the Nkalagu cement factory area, affected agriculture and horticulture as photochemical smog and other heavy metals got into the soil so severely and it became worrisome for people to plant cassava, yam, cocoyam and some other leafy plants (Horsfall and Spiff, 1998).

Therefore, this study is carried out to evaluate the concentration of heavy metals in soils around Champion Breweries and Plasto Crown Company waste disposal sites for comparison with the world permissible standards. This is prompted by the fact that farms and boreholes are located in this area without minding the effects of metal poisoning.

\section{STUDY AREA}

The study area which is located in AkaOffot Industrial Layout, Uyo lies between

U. S. Umana, Department of Geology, University of Calabar, Calabar, Cross River State, Nigeria. 
longitudes $7^{\circ} 55^{\prime} \mathrm{E}-7^{\circ} 56^{\prime} \mathrm{E}$ and latitudes $5^{\circ} 00^{\prime} \mathrm{N}$ $-5^{\circ} 01^{\prime} \mathrm{N}$ (Figure 1). Ikot Ayan village in Ediene, Ikono Local Government Area of Akwa Ibom State, chosen as the control site lies between longitudes $7^{\circ} 45^{\prime} \mathrm{E}-8^{\circ} 00^{\prime} \mathrm{E}$ and latitudes $5^{\circ} 05^{\prime} \mathrm{N}-$ $5^{\circ} 15^{\prime} \mathrm{N}$. The area is located within a coastal plain that generally has a level to gently undulating topography with a gradient of less than five per cent (Tahal, 1979; Okoji, 1988). The surface geology is unconsolidated sand formations ranging from coarse to fine sands. The soil is generally very porous and weakly structured with moderate nutrient and water retention capacity. 


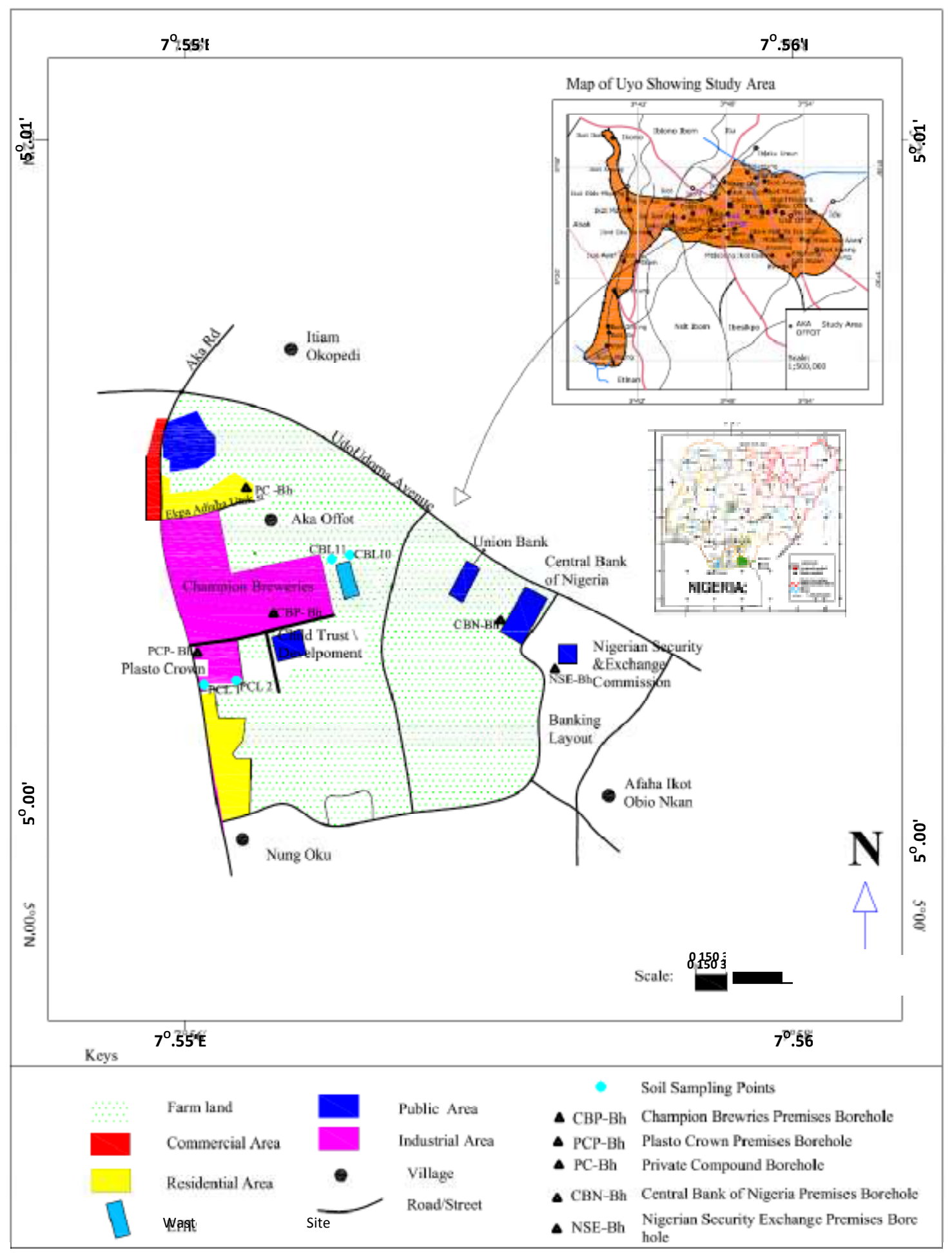

FIGURE 1: Aka Offot Industrial Layout, Uyo showing Champion Breweries PIc and Plasto Crown Company (study area) and sampling points

Source: Agate Geographic Services (2008) 


\section{METHOD OF STUDY}

Soil and sludge samples were collected within the Champion Breweries and Plasto Crown Company waste disposal sites during wet and dry seasons. Sludge samples were collected at nine locations in Champion Breweries wastewater disposal site through purposive sampling method as well as the control site with the aid of a soil auger and put in steriled bags while two depths: $0-15 \mathrm{~cm}$ (surface) and $15-30 \mathrm{~cm}$ (subsurface) soil samples were also collected through purposive sampling method within the Champion Breweries and Plasto Crown Company waste dump sites (Figure 1) with the aid of a soil auger and put separately in labeled steriled containers. The same samples in the control site were equally collected. They were transported to the laboratory for digestion. The soil and sludge samples were air dried (at room temperature); grinded with a wooden roller and sieved via a $2 \mathrm{~mm}$ mesh. The soil $\mathrm{pH}$ was determined using the routine method of International Institute for Tropical Agriculture (1979). Heavy metals of the soil/sludge were extracted by digestion of the samples with a mixture of concentrated $\mathrm{HNO}_{3}$ and HCL. The content of each metal was determined from the samples after due calibration runs using appropriate salts investigated. They were analyzed using a computerized atomic absorption spectrophotometer (AAS) UNICAM model 939, using Whitehead (1979) method.

\section{RESULTS AND DISCUSSION}

The results of the physical properties and heavy metal concentrations in soil and sludge samples of the study area and the control site are presented in Tables 1, 2, 3 and 4 (wet and dry seasons). They are hereby summarized in mean values for both seasons for comparison with the world threshold standards for discussion.

Sludge Sample Analyses - Sludge in this context refers to the semi-solid residue deposited at the bottom of the Champion Breweries wastewater disposal site and the one deposited in a dug well at the control site through surface water.

The sludge $\mathrm{pH}$ mean values for wet and dry seasons are 7.89 and 5.93 while the control site has 6.54 and 5.26 for wet and dry seasons. The $\mathrm{pH}$ value of 7.89 during wet season which signifies alkaline medium is outside the natural range of acidic medium for soils in the Niger
Delta region of Nigeria. The alkaline medium in $\mathrm{pH}$ is attributed to the high calcium content of the brewery effluent thereby forming lime to neutralize the acidic medium of the soil (Orhue et al, 2005).The mean values of electrical conductivity (EC) are $0.21 \mathrm{dSm}^{-1}$ and $0.251 \mathrm{dSm}^{-}$

${ }^{1}$ for wet and dry seasons. The EC values for the control site are $0.04 \mathrm{dSm}^{-1}, 0.251 \mathrm{dSm}^{-1}$ for wet and dry seasons. This indicates the high values of EC in the industrial complex.

In terms of heavy metals, the Iron (Fe) mean values for wet and dry seasons are $1848.1 \mathrm{mg} / \mathrm{kg}$ and $2092.3 \mathrm{mg} / \mathrm{kg}$ (Tables 1 and 2). The control site is $876 \mathrm{mg} / \mathrm{kg}$ for wet season and $907 \mathrm{mg} / \mathrm{kg}$ for dry season. The values are below the world threshold standards. Mean zinc value is $17.44 \mathrm{mg} / \mathrm{kg}$ for wet and $22.25 \mathrm{mg} / \mathrm{kg}$ for dry seasons. The control site value is $1.47 \mathrm{mg} / \mathrm{kg}$ for wet season and $2.94 \mathrm{mg} / \mathrm{kg}$ for dry season, indicating higher concentrations in the industrial area. Equally, manganese mean values for wet and dry seasons are $19.17 \mathrm{mg} / \mathrm{kg}$ and $23.07 \mathrm{mg} / \mathrm{kg}$ (Tables 1 and 2), and $2.68 \mathrm{mg} / \mathrm{kg}$ and $4.15 \mathrm{mg} / \mathrm{kg}$ for wet and dry seasons in the control site. The lead mean value is $11.95 \mathrm{mg} / \mathrm{kg}$ for wet season and $15.67 \mathrm{mg} / \mathrm{kg}$ for dry season. The control site is $0.329 \mathrm{mg} / \mathrm{kg}$ for wet and $0.825 \mathrm{mg} / \mathrm{kg}$ for dry seasons, indicating higher concentrations in the industrial area though below the world threshold standards.

However, despite the fact that all the analyses carried out on sludge and soil in the study area fell within the tolerable levels in terms of heavy metal concentrations, there is need for adequate waste disposal method as well as periodical assessment to avoid unpleasant consequences. This would guide against any negative development in this area as Umana (2010) observed during his reconnaissance survey that Champion Breweries and Plasto Crown Company disposed their wastes into the larger environment without proper treatment. This is in line with Martins (1978) as he observed that some industrial establishments in Nigeria dispose non-processed solid wastes indiscriminately within their premises.

Furthermore, Asia et al. (2007) collected soil and water samples from four locations for analyses of their heavy metals around an oil well head, flare site, waste pit and effluent discharge point in exploration areas in the Niger Delta area. The results showed that lead, copper, cadmium, iron and chromium were higher than the 
permissible limits for heavy metals in the tropical soils signifying pollution of the soil. Equally, analyses carried out by Adediran et al. (2004) on water, soil and plants due to effluent discharge from a brewery industry to the territory of three rural communities in Ibadan showed higher concentrations of cadmium, chromium, copper and nickel in most of the water samples than the World Health Organization permissible standards while some elements such as copper, iron and manganese in soil and plant analyses were higher than the permissible standards.

Also, the mean chromium value for wet season is $6.29 \mathrm{mg} / \mathrm{kg}$ and $9.57 \mathrm{mg} / \mathrm{kg}$ for dry season (Tables 1 and 2 ). The $\mathrm{cr}$ value in the sludge from the control site is $0.063 \mathrm{mg} / \mathrm{kg}$ for wet season and $0.095 \mathrm{mg} / \mathrm{kg}$ for dry season. Accordingly, the mean cadmium value during wet season is $1.89 \mathrm{mg} / \mathrm{kg}$ and $2.51 \mathrm{mg} / \mathrm{kg}$ for dry season as well as $0.023 \mathrm{mg} / \mathrm{kg}$ and $0.078 \mathrm{mg} / \mathrm{kg}$ for wet and dry seasons in the control site recording higher concentrations in the industrial area. One of the major sources of chromium into the environment is industrial discharge although contamination occasionally arises from the use of sewage sludge when added to land. Exposure to it can bring about cancer and malignant growth in the respiratory tract and painless perforation of the nasal spectrum (WHO, 1984). More so, cobalt mean value is $0.07 \mathrm{mg} / \mathrm{kg}$ for wet season and $1.63 \mathrm{mg} / \mathrm{kg}$ for dry season. The control site cobalt concentrations are $0.033 \mathrm{mg} / \mathrm{kg}$ and $0.043 \mathrm{mg} / \mathrm{kg}$ for wet and dry seasons, indicating higher concentrations in the industrial area (Tables 1 and 2). According to Wills (1966) effects of excess intake of cobalt include vomiting, diarrhoea and damaged nerves. Incidence of goiter is higher in regions with higher levels of cobalt in water and soil.

TABLE 1: $\mathrm{pH}$, electrical conductivity and heavy metal concentrations in sludge of Champion Breweries waste water disposal and control sites for wet season.

Wet Season

\begin{tabular}{lllllll}
\hline Parameters & Range & Mean & SD & CV(\%) & SE & $\begin{array}{l}\text { Control } \\
\text { site }\end{array}$
\end{tabular}

A. physical properties

$\mathrm{pH}$

Electrical conductivity $\left(\mathrm{dSm}^{-1}\right)$

7.67-8.20

$0.111-0.518$

7.89

0.21

0.1477

0.1278

1.8712

60.3399

$0.0492 \pm 7.8933$

$0.0426 \pm 0.2118$

6.54

0.040

\author{
B) Heavy metals \\ Iron (Fe) (mg/kg) \\ Zinc (Zn) (mg/kg) \\ Manganese $(\mathrm{Mn})(\mathrm{mg} / \mathrm{kg})$ \\ Lead $(\mathrm{Pb})(\mathrm{mg} / \mathrm{kg})$ \\ Chromium (Cr) (mg/kg) \\ Cadmium (Cr) (mg/kg) \\ Cobalt (Co) (mg/kg)
}

$\begin{array}{llllll}1800-1984 & 1848.11 & 56.642 & 3.0648 & 18.881 \pm 1848.111 & 876 \\ 0.73-31.60 & 17.44 & 10.3958 & 59.5976 & 3.4652 \pm 17.4433 & 1.47 \\ 14.18-22.27 & 19.17 & 3.1965 & 16.6755 & 1.0655 \pm 19.1688 & 2.68 \\ 5.451-16.32 & 11.95 & 4.8495 & 40.5666 & 1.6165 \pm 11.9544 & 0.329 \\ 2.942-8.466 & 6.29 & 2.2683 & 36.0734 & 0.7561 \pm 6.2880 & 0.063 \\ 1.163-2.905 & 1.89 & 0.7351 & 38.8531 & 0.2450 \pm 1.8920 & 0.023 \\ 0.047-0.094 & 0.07 & 0.0176 & 23.6877 & 0.0058 \pm 0.0743 & 0.033\end{array}$

Note: $\mathrm{SD}=$ standard deviation; $\mathrm{CV}=$ coefficient of variability and $\mathrm{SE}=$ standard error . Source: Author's Fieldwork. 
TABLE 2: $\mathrm{pH}$, electrical conductivity and heavy metal concentrations in sludge of Champion Breweries wastewater disposal and control sites for dry season.

\section{Dry Season}

\begin{tabular}{|c|c|c|c|c|c|c|}
\hline Parameters & Range & Mean & SD & CV(\%) & SE & $\begin{array}{l}\text { Control } \\
\text { site }\end{array}$ \\
\hline $\begin{array}{l}\text { A. physical properties } \\
\mathrm{pH} \\
\text { Electrical conductivity }\left(\mathrm{dsm}^{-1}\right)\end{array}$ & $\begin{array}{l}5.30-6.43 \\
0.059-0.931\end{array}$ & $\begin{array}{l}5.93 \\
0.52\end{array}$ & $\begin{array}{l}0.4920 \\
0.4236\end{array}$ & $\begin{array}{l}8.296 \\
81.46\end{array}$ & $\begin{array}{l}0.1564 \pm 5.93 \\
0.1441 \pm 0.52\end{array}$ & $\begin{array}{l}5.26 \\
0.251\end{array}$ \\
\hline $\begin{array}{l}\text { B) Heavy metals } \\
\text { Iron }(\mathrm{Fe})(\mathrm{mg} / \mathrm{kg}) \\
\text { Zinc }(\mathrm{Zn})(\mathrm{mg} / \mathrm{kg}) \\
\text { Manganese }(\mathrm{Mn})(\mathrm{mg} / \mathrm{kg}) \\
\text { Lead }(\mathrm{Pb})(\mathrm{mg} / \mathrm{kg}) \\
\text { Chromium }(\mathrm{Cr})(\mathrm{mg} / \mathrm{kg}) \\
\text { Cadmium }(\mathrm{Cr})(\mathrm{mg} / \mathrm{kg}) \\
\text { Cobalt }(\mathrm{Co})(\mathrm{mg} / \mathrm{kg})\end{array}$ & $\begin{array}{l}2008-2180 \\
5.03-35.19 \\
15.36-29.86 \\
8.112-21.94 \\
6.312-12.06 \\
1.854-3.409 \\
1.075-2.016\end{array}$ & $\begin{array}{l}2092.33 \\
22.25 \\
23.07 \\
15.67 \\
9.57 \\
2.51 \\
1.63\end{array}$ & $\begin{array}{l}55.959 \\
12.783 \\
5.7565 \\
5.7896 \\
1.4912 \\
0.6673 \\
0.3931\end{array}$ & $\begin{array}{l}2.674 \\
62.91 \\
24.95 \\
36.947 \\
15.58 \\
26.59 \\
24.12\end{array}$ & $\begin{array}{l}18.65 \pm 2092.33 \\
4.261 \pm 20.32 \\
1.9188 \pm 23.07 \\
1.9298 \pm 15.67 \\
0.497 \pm 9.57 \\
0.222 \pm 2.51 \\
0.131 \pm 1.63\end{array}$ & $\begin{array}{l}907 \\
2.94 \\
4.15 \\
0.825 \\
0.095 \\
0.078 \\
0.043\end{array}$ \\
\hline
\end{tabular}

Note: $\mathrm{SD}=$ Standard deviation; $\mathrm{CV}=$ coefficient of variability and SE=standard error .

Source: Author's Fieldwork.

Soil Sample Analyses - The soil pH mean values close to Champion Breweries wastewater disposal site are 5.92 and 5.30 for wet and dry seasons; 7.42 (wet season) and 6.25 (dry season) for Plasto Crown waste disposal site while the control site has 5.25 and 5.65 for wet and dry seasons. $7.42 \mathrm{pH}$ value which is alkaline is outside the natural range of acidic medium for soils in the Niger Delta region of Nigeria (Orhue et al, 2005). This means that the remnants of the wastes have formed lime to neutralize the acidic medium of the soil.

The mean electrical conductivity for samples near Champion Breweries is $1.066 \mathrm{dSm}^{-}$ 1 (wet season) and $1.062 \mathrm{dSm}^{-1}$ (dry season); $0.665 \mathrm{dSm}^{-1}$ (wet season) and $1.040 \mathrm{dSm}^{-1}$ (dry season) for Plasto Crown waste disposal site while the control site has $0.089 \mathrm{dSm}^{-1}$ and 0.075 $\mathrm{dSm}^{-1}$ for wet and dry seasons. These values are below $4 \mathrm{dSm}^{-1}$ permissible level, which indicate that the soils are non-saline (Miller and Donahue, 1995). Heavy metals, iron mean values near Champion Breweries wastewater disposal site for wet and dry seasons are $1898.25 \mathrm{mg} / \mathrm{kg}$ and $2014.5 \mathrm{mg} / \mathrm{kg} ; 2211.75 \mathrm{mg} / \mathrm{kg}$ and $2316.75 \mathrm{mg} / \mathrm{kg}$ wet and dry seasons for Plasto Crown waste disposal site as well as $1125.5 \mathrm{mg} / \mathrm{kg}$ and $1099.5 \mathrm{mg} / \mathrm{kg}$ (wet and dry seasons) for the control site. These values are within the permissible limits for iron of 10,000100,000 mg/kg (Brady and Weil, 1996).

The mean zinc values near Champion Breweries wastewater disposal site are $13.33 \mathrm{mg} / \mathrm{kg}$ and $22.39 \mathrm{mg} / \mathrm{kg}$ for wet and dry seasons; $58.53 \mathrm{mg} / \mathrm{kg}$ and $63.05 \mathrm{mg} / \mathrm{kg}$ (wet and dry seasons) for Plasto Crown waste disposal site while the control site has $2.42 \mathrm{mg} / \mathrm{kg}$ (wet) and $2.52 \mathrm{mg} / \mathrm{kg}$ for dry season. The results show that zn concentrations in the Plasto Crown waste disposal site were higher than that of the Champion Breweries site but within the 10$300 \mathrm{mg} / \mathrm{kg}$ permissible level of Brady \& Weil (1996). In terms of lead, the mean values near Champion Breweries site is $9.10 \mathrm{mg} / \mathrm{kg}$ (wet season) and $14.96 \mathrm{mg} / \mathrm{kg}$ (dry season); Plasto Crown waste disposal site are $21.32 \mathrm{mg} / \mathrm{kg}$, $31.20 \mathrm{mg} / \mathrm{kg}$ (wet and dry seasons) while $1.109 \mathrm{mg} / \mathrm{kg}$ and 1.541 (wet and dry seasons) are for the control site. The nickel mean values near Champion Breweries waste disposal site is $7.86 \mathrm{mg} / \mathrm{kg}$ and $9.745 \mathrm{mg} / \mathrm{kg}$ (wet and dry seasons; $34.19 \mathrm{mg} / \mathrm{kg}$ and $25.32 \mathrm{mg} / \mathrm{kg}$ (wet and 
dry seasons) for Plasto Crown waste disposal site while the control site has $1.035 \mathrm{mg} / \mathrm{kg}$ and $1.302 \mathrm{mg} / \mathrm{kg}$ for wet and dry seasons (Tables $3 \&$ 4). These ranges are within the nickel permissible limits of $10-1000 \mathrm{mg} / \mathrm{kg}$ for tropical soils (Line et al, 1987).

According to Ademoroti (1996), most industrial activities lead to enrichment of heavy metals in water, air and land. This conforms with the submission of Gulson et al. (1981) that trace metals most commonly associated with manmade pollution of soils are boron, cadmium, cobalt, chromium, copper, nickel, lead and zinc. These elements constitute essential micronutrients to plants as well as components of vitamins, the enzyme system, hormones to human but, in higher concentrations than normal, they affect man through food chain.

Chromium mean values near Champion Breweries wastewater disposal site for wet and dry seasons are $1.99 \mathrm{mg} / \mathrm{kg}$ and $2.44 \mathrm{mg} / \mathrm{kg}$; $14.14 \mathrm{mg} / \mathrm{kg}$ and $9.5914 \mathrm{mg} / \mathrm{kg}$ (wet and dry seasons) for Plasto Crown waste disposal site while the control site has $0.763 \mathrm{mg} / \mathrm{kg}$ (wet season) and $0.759 \mathrm{mg} / \mathrm{kg}$ (dry season); Plasto Crown waste disposal site has higher values than the Champion Breweries wastewater disposal site but within permissible limits of $10-1000 \mathrm{mg} / \mathrm{kg}$ (Bohn et al., 1985), Cadmium mean value near
Champion Breweries wastewater disposal site are $0.309 \mathrm{mg} / \mathrm{kg}$ and $0.512 \mathrm{mg} / \mathrm{kg}$ (wet and dry seasons); $0.76 \mathrm{mg} / \mathrm{kg}$ and $0.87 \mathrm{mg} / \mathrm{kg}$ (wet and dry seasons) for Plasto Crown waste disposal site whereas the control site has $0.016 \mathrm{mg} / \mathrm{kg}$ and $0.025 \mathrm{mg} / \mathrm{kg}$ (wet and dry seasons). These values fall within cadmium permissible limits of $0.1-7 \mathrm{mg} / \mathrm{kg}$ (Brady and Weil, 1996).

Equally, mercury mean values near Champion Breweries wastewater disposal site for wet and dry seasons are $0.058 \mathrm{mg} / \mathrm{kg}$ and 0.061 $\mathrm{mg} / \mathrm{kg} ; 0.152 \mathrm{mg} / \mathrm{kg}$ and $0.124 \mathrm{mg} / \mathrm{kg}$ for Plasto Crown waste disposal site (wet and dry seasons) as well as $0.005 \mathrm{mg} / \mathrm{kg}$ and $0.047 \mathrm{mg} / \mathrm{kg}$ (wet and dry seasons) for the control site (Tables 3 \& 4). The Plasto Crown waste disposal site records higher concentrations than Champion Breweries wastewater disposal site. There is need to avoid excess accumulation of this metal in soils of this area because of its health implications such as impaired vision, muscular convulsion, madness and paralysis (Goldwater, 1972). Subsequently, a two-way analysis of variance (ANOVA) statistical method used in running the test shows that the soil in terms of heavy metal concentrations, do not significantly exceed the world permissible standards (F-ratio=1.01798; F-critical=3.48103; $p>0.05$ ) (Table 5). 
TABLE 3: $\mathrm{pH}$, electrical conductivity $(E C)$ and heavy metal concentrations in soil sampled in Champion Breweries, Plasto Crown Company waste disposal and control sites for wet season.

Champion Breweries

\begin{tabular}{|c|c|c|c|c|c|c|c|}
\hline Parameters & Range & Mean & SD & $\mathrm{CV}(\%)$ & SE & $\begin{array}{l}\text { Control } \\
\text { site } \\
\text { (mean) }\end{array}$ & $\begin{array}{l}\text { Maximum } \\
\text { permissible } \\
\text { limits }\end{array}$ \\
\hline $\mathrm{pH}$ & $\begin{array}{l}5.76- \\
6.06\end{array}$ & 5.92 & 0.14975 & 2.5295 & $\begin{array}{l}0.074875 \\
\pm 5.9175\end{array}$ & 5.25 & $5.1-6.5^{*}$ \\
\hline$E C\left(d_{S m}^{-1}\right)$ & $\begin{array}{l}1.003- \\
1.148\end{array}$ & 1.066 & 0.071267 & 6.6854 & $\begin{array}{l}0.035634 \\
\pm 1.0655\end{array}$ & 0.089 & $2-4 \mathrm{dSm}^{-1^{*}}$ \\
\hline Iron $(\mathrm{Fe})(\mathrm{mg} / \mathrm{kg})$ & $\begin{array}{l}1673- \\
2103\end{array}$ & 1898.25 & 7894.31 & 4.1587 & $\begin{array}{l}3947.155 \\
\pm 5898.25\end{array}$ & 1125.5 & $\begin{array}{l}10,000- \\
100,000 \\
\mathrm{mg} / \mathrm{kg}^{*}\end{array}$ \\
\hline Zinc $(\mathrm{Zn})(\mathrm{mg} / \mathrm{kg})$ & $\begin{array}{l}11.41- \\
16.44\end{array}$ & 13.33 & 2.203096 & 16.5273 & $\begin{array}{l}1.101548 \\
\pm 13.325\end{array}$ & 2.43 & $\begin{array}{l}10-300 \\
\mathrm{mg} / \mathrm{kg}^{*}\end{array}$ \\
\hline Lead $(\mathrm{Pb})(\mathrm{mg} / \mathrm{kg})$ & $\begin{array}{l}6.98- \\
12.85\end{array}$ & 9.10 & 2.603626 & 28.6112 & $\begin{array}{l}1.301813 \\
\pm 9.100\end{array}$ & 1.109 & $2-200 \mathrm{mg} / \mathrm{kg}^{*}$ \\
\hline Nickel (Ni) (mg/kg) & $\begin{array}{l}6.44- \\
8.81\end{array}$ & 7.86 & 1.105712 & 14.0675 & $\begin{array}{l}0.552856 \\
\pm 7.86\end{array}$ & 1.035 & $\begin{array}{l}10- \\
1000 \mathrm{mg} / \mathrm{kg}^{* * *}\end{array}$ \\
\hline Chromium(Cr)(mg/kg) & $\begin{array}{l}1.82- \\
2.16\end{array}$ & 1.99 & 0.147196 & 7.3967 & $\begin{array}{l}0.0737598 \\
\pm 1.99\end{array}$ & 0.763 & 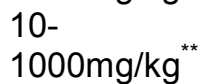 \\
\hline $\begin{array}{l}\text { Cadmium } \\
(\mathrm{mg} / \mathrm{kg})\end{array}$ & $\begin{array}{l}0.219- \\
0.402\end{array}$ & 0.309 & 0.074999 & 24.2715 & $\begin{array}{l}0.0375 \pm \\
0.30975\end{array}$ & 0.016 & $0.1-7 \mathrm{mg} / \mathrm{kg}^{*}$ \\
\hline Mercury $(\mathrm{Hg})(\mathrm{mg} / \mathrm{kg})$ & $\begin{array}{l}0.041- \\
0.072\end{array}$ & 0.058 & 0.01372 & 23.6551 & $\begin{array}{l}0.00686 \pm \\
0.05825\end{array}$ & 0.005 & \\
\hline
\end{tabular}

\begin{tabular}{|c|c|c|c|c|c|c|c|}
\hline Parameters & Range & Mean & SD & $\mathrm{CV}(\%)$ & SE & $\begin{array}{l}\text { Control } \\
\text { site } \\
\text { (mean) }\end{array}$ & $\begin{array}{l}\text { Maximum } \\
\text { permissible } \\
\text { limits }\end{array}$ \\
\hline $\mathrm{Ph}$ & $\begin{array}{l}7.04- \\
7.92\end{array}$ & 7.42 & 0.408932 & 5.5112 & $\begin{array}{l}0.204466 \\
\pm 7.4225\end{array}$ & 5.25 & $5.1-6.5^{*}$ \\
\hline$E C\left(d \mathrm{dm}^{-1}\right)$ & $\begin{array}{l}0.010- \\
0.011\end{array}$ & 0.665 & 0.544394 & 81.8637 & $\begin{array}{l}0.272197 \\
\pm 0.665\end{array}$ & 0.089 & $2-4 \mathrm{dSm}^{-1^{*}}$ \\
\hline Iron (Fe) (mg/kg) & $\begin{array}{l}2014- \\
2043\end{array}$ & 2211.75 & 275.1925 & 12.4422 & $\begin{array}{l}137.5963 \\
\pm 2211.75\end{array}$ & 1125.5 & $\begin{array}{l}10,000- \\
100,000 \\
\mathrm{mg}^{*} \mathrm{~kg}^{*}\end{array}$ \\
\hline Zinc $(\mathrm{Zn})(\mathrm{mg} / \mathrm{kg})$ & $\begin{array}{l}52.10- \\
60.97\end{array}$ & 58.53 & 4.299992 & 7.3466 & $\begin{array}{l}2.14996 \pm \\
58.53\end{array}$ & 2.43 & $\begin{array}{l}10-300 \\
\mathrm{mg} / \mathrm{kg}^{*}\end{array}$ \\
\hline Lead $(\mathrm{Pb})(\mathrm{mg} / \mathrm{kg})$ & $\begin{array}{l}18.08- \\
24.91\end{array}$ & 21.32 & 2.914543 & 13.6704 & $\begin{array}{l}1.457271 \\
\pm 21.3225\end{array}$ & 1.109 & $\begin{array}{l}2-200 \\
\mathrm{mg} / \mathrm{kg}\end{array}$ \\
\hline Nickel (Ni) (mg/kg) & $\begin{array}{l}30.19- \\
38.16\end{array}$ & 34.19 & 3.254499 & 9.5188 & $\begin{array}{l}1.62725 \pm \\
34.185\end{array}$ & 1.035 & $\begin{array}{l}10-1000 \\
\mathrm{mg} / \mathrm{kg}^{* \star *}\end{array}$ \\
\hline Chromium(Cr)(mg/kg) & $\begin{array}{l}10.40- \\
19.00\end{array}$ & 14.14 & 4.112355 & 29.0831 & $\begin{array}{l}2.056178 \\
\pm 14.14\end{array}$ & 0.763 & $\begin{array}{l}10-1000 \\
\mathrm{mg} / \mathrm{kg}\end{array}$ \\
\hline $\begin{array}{l}\text { Cadmium } \\
(\mathrm{mg} / \mathrm{kg})\end{array} \quad(\mathrm{Cd})$ & $\begin{array}{l}0.296- \\
0.927\end{array}$ & 0.76 & 0.30903 & 40.6618 & $\begin{array}{l}0.154515 \\
\pm 0.75925\end{array}$ & 0.016 & $0.1-7 \mathrm{mg} / \mathrm{kg}^{\star}$ \\
\hline Mercury $(\mathrm{Hg})(\mathrm{mg} / \mathrm{kg})$ & $\begin{array}{l}0.108- \\
0.214\end{array}$ & 0.152 & 0.046869 & 30.8348 & $\begin{array}{l}0.023434 \\
\pm 0.152\end{array}$ & 0.005 & \\
\hline
\end{tabular}

Note: $\quad$ *Brady and Weil (1996) ** Bohn et al, (1985); *** Line et al. (1987).

$\mathrm{SD}=$ standard deviation; $\mathrm{CV} \%=$ coefficient of variability; SE = standard error.

Source: Author's Field work. 
TABLE 4: $\mathrm{pH}$, electrical conductivity (EC) and heavy metal concentrations in soil sampled in Champion Breweries, Plasto Crown Company waste disposal and control sites for dry season.

Champion Breweries

\begin{tabular}{|c|c|c|c|c|c|c|c|}
\hline Parameters & Range & Mean & SD & $C V(\%)$ & SE & $\begin{array}{l}\text { Control } \\
\text { site } \\
\text { (mean) }\end{array}$ & $\begin{array}{l}\text { Maximum } \\
\text { permissible } \\
\text { limits }\end{array}$ \\
\hline $\mathrm{pH}$ & $\begin{array}{l}5.42- \\
5.59\end{array}$ & 5.50 & 0.075277 & 1.3698 & $\begin{array}{ll}0.038 \quad \pm \\
5.5\end{array}$ & 5.65 & $5.1-6.5^{*}$ \\
\hline$E C\left(d S m^{-1}\right)$ & $\begin{array}{l}1.005- \\
1.120\end{array}$ & 1.062 & 0.064407 & 6.0646 & $\begin{array}{l}0.032 \\
1.06225\end{array} \pm$ & 0.075 & $2-4 \mathrm{dSm}^{-1^{*}}$ \\
\hline Iron $(\mathrm{Fe})(\mathrm{mg} / \mathrm{kg})$ & $\begin{array}{l}1189- \\
2116\end{array}$ & 2014.5 & 93.81009 & 4.567 & $\begin{array}{l}46.90505 \\
\pm 2014.5\end{array}$ & 1099.5 & $\begin{array}{l}10,000- \\
100,000 \\
\mathrm{mg} / \mathrm{kg}^{*}\end{array}$ \\
\hline Zinc $(\mathrm{Zn})(\mathrm{mg} / \mathrm{kg})$ & $\begin{array}{l}16.11- \\
27.63\end{array}$ & 22.39 & 5.747373 & 25.6693 & $\begin{array}{l}2.873687 \\
\pm 22.385\end{array}$ & 2.52 & $\begin{array}{l}10-300 \\
\mathrm{mg} / \mathrm{kg}^{* *}\end{array}$ \\
\hline Lead $(\mathrm{Pb})(\mathrm{mg} / \mathrm{kg})$ & $\begin{array}{l}6.98- \\
19.64\end{array}$ & 14.96 & 4.574895 & 30.5808 & $\begin{array}{l}2.287448 \\
\pm 14.96\end{array}$ & 1.541 & $2-200 \mathrm{mg} / \mathrm{kg}^{*}$ \\
\hline Nickel (Ni) (mg/kg) & $\begin{array}{l}8.73- \\
10.85\end{array}$ & 9.745 & 0.934398 & 9.5679 & $\begin{array}{l}0.4462 \\
\pm 9.745\end{array}$ & 1.302 & $\begin{array}{l}10- \\
1000 \mathrm{mg} / \mathrm{kg}^{* * *}\end{array}$ \\
\hline Chromium $(\mathrm{Cr})(\mathrm{mg} / \mathrm{kg})$ & $\begin{array}{l}1.98- \\
3.02\end{array}$ & 2.44 & 0.495042 & 20.2886 & $\begin{array}{l}0.247521 \\
\pm 2.44\end{array}$ & 0.759 & $\begin{array}{l}10- \\
1000 \mathrm{mg} / \mathrm{kg}^{* *}\end{array}$ \\
\hline $\begin{array}{l}\text { Cadmium } \\
(\mathrm{mg} / \mathrm{kg})\end{array} \quad(\mathrm{Cd})$ & $\begin{array}{l}0.416- \\
0.603\end{array}$ & 0.512 & 0.077037 & 15.0462 & $\begin{array}{l}0.03851 \pm \\
0.51165\end{array}$ & 0.025 & $0.1-7 \mathrm{mg} / \mathrm{kg}$ \\
\hline Mercury $(\mathrm{Hg})(\mathrm{mg} / \mathrm{kg})$ & $\begin{array}{l}0.037- \\
0.088\end{array}$ & 0.061 & 0.024663 & 40.4311 & $\begin{array}{l}0.012331 \\
\pm 0.06075\end{array}$ & 0.047 & \\
\hline
\end{tabular}

\begin{tabular}{|c|c|c|c|c|c|c|c|}
\hline Parameters & Range & Mean & SD & $\mathrm{CV}(\%)$ & SE & $\begin{array}{l}\text { Control } \\
\text { site } \\
\text { (mean) }\end{array}$ & $\begin{array}{l}\text { Maximum } \\
\text { permissible } \\
\text { limits }\end{array}$ \\
\hline$p^{H}$ & $\begin{array}{l}5.95- \\
6.95\end{array}$ & 6.25 & 0.464283 & 7.4285 & $\begin{array}{l}0.232141 \\
\pm 6.2625\end{array}$ & 5.65 & $5.1-6.5^{*}$ \\
\hline $\mathrm{EC}\left(\mathrm{dSm}^{-1}\right)$ & $\begin{array}{l}0.918- \\
1.315\end{array}$ & 1.040 & 0.190566 & 18.32236 & $\begin{array}{l}0.095283 \\
\pm \\
1.03925\end{array}$ & 0.075 & $2-4 \mathrm{dSm}^{-1 \times}$ \\
\hline Iron (Fe) (mg/kg) & $\begin{array}{l}2106- \\
2811\end{array}$ & 2316.75 & 335.8605 & 14.4970 & $\begin{array}{l}167.9302 \\
\pm \\
2316.75\end{array}$ & 1099.5 & $\begin{array}{l}10,000- \\
100,000 \\
\mathrm{mg} / \mathrm{kg}^{*}\end{array}$ \\
\hline Zinc (Zn) (mg/kg) & $\begin{array}{l}61.35- \\
62.69\end{array}$ & 63.05 & 3.555475 & 5.6391 & $\begin{array}{l}1.777737 \\
\pm 63.04\end{array}$ & 2.52 & $\begin{array}{l}10-300 \\
\mathrm{mg} / \mathrm{kg}^{*}\end{array}$ \\
\hline Lead (Pb) (mg/kg) & $\begin{array}{l}31.14- \\
36.18\end{array}$ & 31.20 & 4.722936 & 15.1376 & $\begin{array}{l}2.361468 \\
\pm \\
31.20375\end{array}$ & 1.541 & $\begin{array}{l}2-200 \\
\mathrm{mg} / \mathrm{kg}\end{array}$ \\
\hline Nickel (Ni) (mg/kg) & $\begin{array}{l}20.01- \\
28.97\end{array}$ & 25.32 & 4.127722 & 16.3022 & $\begin{array}{l}2.063861 \\
\pm \\
25.3225\end{array}$ & 1.302 & $\begin{array}{l}10-1000 \\
\mathrm{mg} / \mathrm{kg}^{* * *}\end{array}$ \\
\hline Chromium(Cr)(mg/kg) & $\begin{array}{l}9.11- \\
11.02\end{array}$ & 9.59 & 0.954624 & 9.9543 & $\begin{array}{l}0.477312 \\
\pm \\
9.59025\end{array}$ & 0.759 & $\begin{array}{l}10- \\
1000 \mathrm{mg} / \mathrm{kg}^{* *}\end{array}$ \\
\hline $\begin{array}{l}\text { Cadmium } \\
(\mathrm{mg} / \mathrm{kg})\end{array} \quad(\mathrm{Cd})$ & $\begin{array}{l}0.813- \\
0.917\end{array}$ & 0.87 & 0.060047 & 6.9019 & $\begin{array}{l}0.030024 \\
\pm 0.8655\end{array}$ & 0.025 & $0.1-7 \mathrm{mg} / \mathrm{kg}^{*}$ \\
\hline Mercury $(\mathrm{Hg})(\mathrm{mg} / \mathrm{kg})$ & $\begin{array}{l}0.040- \\
0.217\end{array}$ & 0.124 & 0.072629 & 58.5717 & $\begin{array}{l}0.036315 \\
\pm 0.1235\end{array}$ & 0.047 & \\
\hline
\end{tabular}


Note*: Brady and Weil (1996);** Bohn et.al., (1985);*** Line et al., (1987);

$\mathrm{SD}=$ standard deviation, $\mathrm{CV}(\%)=$ coefficient of variability;

$\mathrm{SE}=$ standard error.

Source: Author's Fieldwork.

TABLE 5: Variations in heavy metals in soils from Champion Breweries and Plasto Company waste disposal sites.

\begin{tabular}{lllllll}
\hline Source of variations & $\begin{array}{l}\text { Sum of } \\
\text { square }\end{array}$ & $\begin{array}{l}\text { Degree of } \\
\text { freedom }\end{array}$ & $\begin{array}{l}\text { Mean sum of } \\
\text { square }\end{array}$ & F-ratio & P-value & F-critical \\
\hline $\begin{array}{l}\text { Heavy metal } \\
\text { concentrations }\end{array}$ & $1.14+11$ & 8 & $1.43 \mathrm{E}+10$ & 1.017981 & 0.490255 & 3.48103 \\
$\begin{array}{l}\text { Treatment } \\
\text { Error (within) }\end{array}$ & $1.42 \mathrm{E}+10$ & 1 & $1.42 \mathrm{E}+10$ & $1.013004 \mathrm{~ns}$ & 0.34653 & 5.31764 \\
& $1.12 \mathrm{E}+11$ & 8 & $1.4 \mathrm{E}+10$ & & & \\
Total & $2.41 \mathrm{E} 11$ & 17 & & & & \\
\hline
\end{tabular}

Note: $n s=$ not significant

\section{SUMMARYICONCLUSION}

The reconnaissance survey carried out within the premises of Champion Breweries and Plasto Crown Company reveals that the two industries did not have any formal waste treatment method before disposal into the larger environment at the time of this study. This contributes to the alkaline soil $\mathrm{pH}$ in this area.

This study reveals that the soils of their waste disposal sites only exceed the control site but do not significantly exceed the world permissible standards in terms of heavy metal concentrations. The results further draw a distinction between the study area and the control site justifying the study area as an industrial complex. However, though the study reveals that heavy metal concentrations in the study area do not significantly exceed the world permissible standards, there is that concern that if these industries continue to dump wastes in this area without prior treatment, a time will come when the concentration of most of these metals will be so high in the soil, so that they become deleterious to this ecosystem thereby bringing adverse effects to the inhabitants of this area, hence the following suggestions for a sustainable environment:
1. Major stakeholders such as the Ministries of Health and Environment should come up with a position by telling people to discontinue farming in this industrial area so as to avoid any form of metal poisoning.

2. The Ministry of Environment should make it mandatory for Champion Breweries and Plasto Crown Company to engage experts in environmental management to come out with measures in ameliorating the effects of wastes already dumped in this area.

3. The management of Champion Breweries should as a matter of urgency install anti-pollution equipment for the treatment of their effluent in line with FEPA ACT (CAP 131) of 1991.

4. The installation of such equipment shall be based on the Best Available Technology (BAT), the Best Practical Technology (BPT) or the Uniform Effluent Standards (UES).

5. The management of Champion Breweries and Plasto Crown Company should as a matter of urgency establish "waste management" units in their industries and equip them with functional machines and qualified personnel with good background in waste management. 


\section{ACKNOWLEDGEMENTS}

The author is very grateful to Iniabasi Obot of the Department of Soil Sciences, University of Uyo, for digesting the samples while Eyo Edet of the Department of Soil Sciences, University of Calabar, is highly appreciated for his numerous contributions for the success of this work especially data interpretation.

\section{REFERENCES}

Adediran, J. A., Taiwo, L. B., Sobulo, R. A., Ogunfowokan, A. O and Fatoki, O. S., 2004. Impact of the effluent discharge from a breweries plant on three communities in Ibadan Municipality, South-western, Nigeria. Global Journal of Pure and Applied Sciences.10, (1): 211-216.

Ademoroti, C. M. A., 1996. Standard methods for water and effluents analysis. Ibadan: Foludex Press.

Agate Geographic Services., 2008. Digitalization of map of Akwa Ibom State: 1997 edition, Uyo: Agate Geographic Services.

Asia, I. O., Jegede, S. I., Jegede, D. A., Izelyamu, O. K and Akpasubi, E. B., 2007. The effects of petroleum exploration and production operations on the heavy metals contents of soil and ground water in the Niger Delta. International Journal of Physical Sciences, 2, (10): 271-275.

Asthana, D. K and Asthana, M., 2001. Environmental problems and solutions $\left(2^{\text {nd }}\right.$ ed.) New Delhi: S. Chad and Company.

Bohn, H. L., McNeal, B. L and O'Connor, G. A., 1985. Soil Chemistry, New York: John Wiley and Sons.

Brady, N. C and Weil, R. R., 1996. The nature and properties of soils $\left(11^{\text {th }}\right.$ ed) Upper Saddle Rider: Prentice Hall.

Federal Environmental Protection Agency (FEPA)., 1991. National Interim guidelines and standards for industrial effluents, gaseous emissions and hazardous waste management in Nigeria: Lagos; Federal Republic of Nigeria, 418-480.
Goldwater, L. J., 1972. Mercury: A history of quick silver. Baltimore: York Press.

Gulson, B. L., Tiler, K. G., Prizon, K. J and Merry, R. H., 1981. Use of lead isotopes in soils to identify the source of lead contamination near Adelaide, South Australia. Environmental Science and Technology, 15, 691-696.

Horsfall, M and Spiff, A. I., 1998. Principles of environmental chemistry, Port Harcourt: Metroprints.

International Institute for Tropical Agriculture (I.I.T.A)., 1979. Selected methods for soil and plant analysis, Ibadan: International Institute for Tropical Agriculture.

Line, M. A., Gerland, C. O and Crowley, M., 1987. Evaluation of land farm remediation of hydrocarbon-contaminated soils at the Railyard, Launceston, Australia, Waste Management, Elsevier Science, 16, 567569.

Martin, M. H., Duncan, E. M and Coughtry, P. I., 1982. The distribution of heavy metals in the woodland ecosystem. Environmental Pollution, 3, (2): 147-156.

Martins, M. A., 1978. A study of industrial effects and waste disposal habits of some industries in the Igamu and Apapa industrial estates of Lagos. Unpublished M.Sc. thesis, University of Ibadan, Nigeria.

Miller, R. W and Donahue, R. L., 1995. Soils in our environment, London: Prentice Hall.

Okoji, M. A., 1988. Soil Resources of Cross River State, Nigeria. Journal of Governmental Management, (26): 28-42.

Orhue, E. R., Osaigboro, A. U and Wrioko, D. E., 2005. Growth of Maize (Zea Mays L.) and changes in some chemical properties of an ultisol amended brewery effluent. African Journal of Biotechnology, 4 (9) 973-978. 
Sule, R. A. O., 2001. Urban environmental pollution. Criticality and synopsis, Calabar: BAAS International Publishers.

Tahal Consultants., 1979. Qua Iboe River Basin Pre-feasibility study, Vol. 2: Soil survey and land capability classification, water resources potentials; fisheries and forestry resources, Ibadan: Tahal Consultants.

Umana, U. S., 2010. The impact of industrial waste disposal on soil and groundwater in Uyo, Akwa lbom State: Champion Breweries Plc and Plasto Crown Company Limited in Perspective. Unpublished M.Sc. Thesis, University of Calabar, Nigeria.

Whitehead, P. J., 1979. An introduction to atomic absorption spectrophotometer (AAS) $\left(1^{\text {st }}\right.$ ed.) New York: Pye Unicam.

Wills, J. H., 1966. Goitrogens in food. In Food Protection Committee (Ed.), Toxicants occurring naturally in food. Washington D. C.: National Academy of Science, 1354-1359.

World Health Organization (WHO)., 1984. Guideline for drinking water quality (iii): Health criteria and supporting information. Geneva: World Health Organization. 